\title{
FLOOD MAGNITUDE AND FREQUENCY OF FRANKLIN POND TRIBUTARY AT THE CULVERT ON NEW JERSEY ROUTE 23, FRANKLIN BOROUGH, SUSSEX COUNTY, NEW JERSEY
}

U.S. GEOLOGICAL SURVEY

Open-File Report 96-327

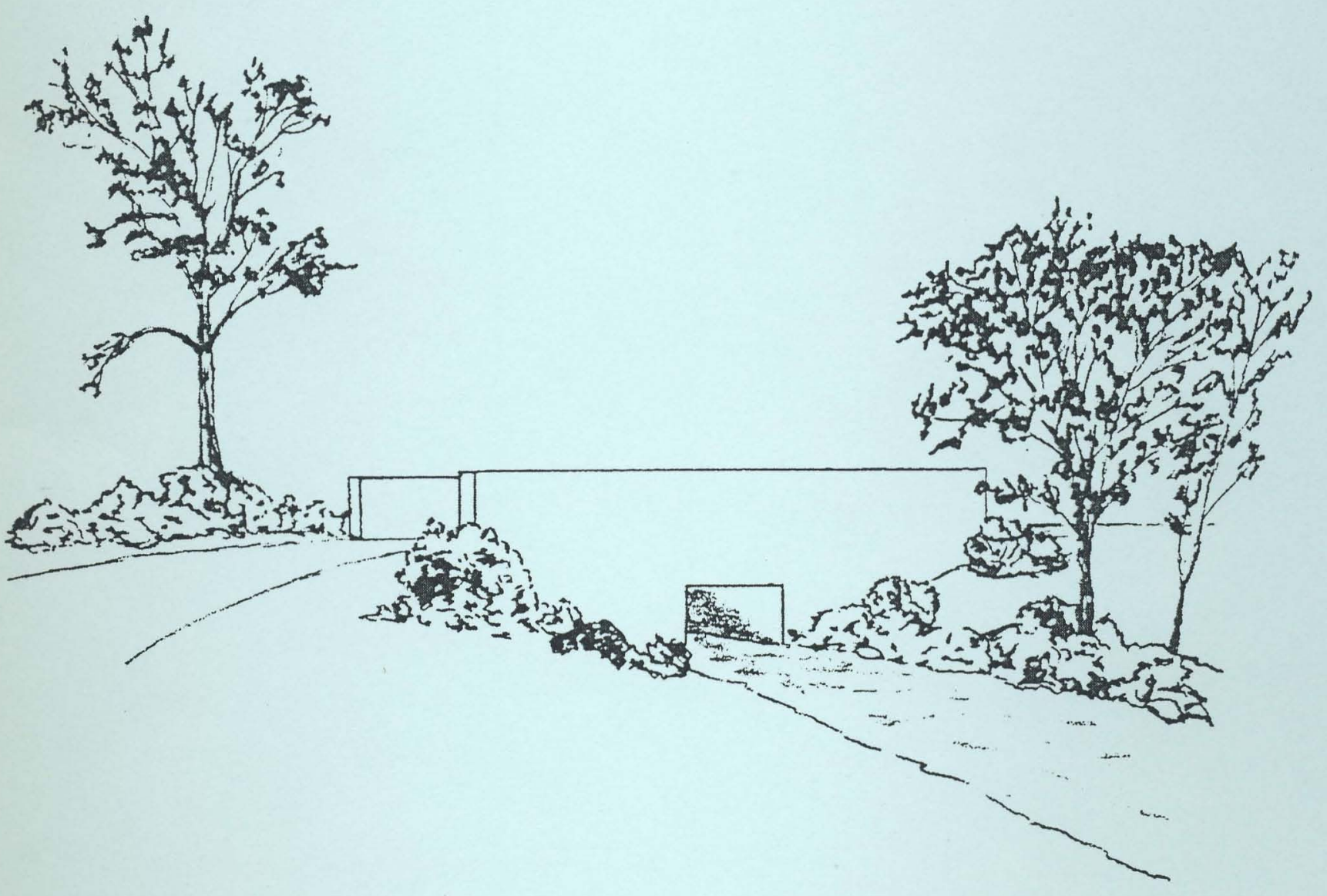

Prepared in cooperation with the

NEW JERSEY DEPARTMENT OF TRANSPORTATION

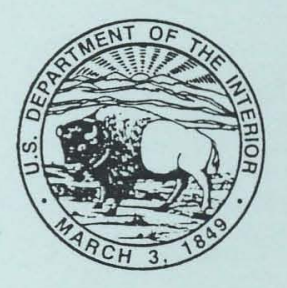




\section{FLOOD MAGNITUDE AND FREQUENCY OF FRANKLIN POND TRIBUTARY AT THE CULVERT ON NEW JERSEY ROUTE 23, FRANKLIN BOROUGH, SUSSEX COUNTY, NEW JERSEY}

By Thomas Barringer

U.S. GEOLOGICAL SURVEY

Open-File Report 96-327

Prepared in cooperation with the

NEW JERSEY DEPARTMENT OF TRANSPORTATION

West Trenton, New Jersey 


\section{U.S. DEPARTMENT OF THE INTERIOR}

BRUCE BABBIT, Secretary

\section{U.S. GEOLOGICAL SURVEY}

Gordon P. Eaton, Director

For additional information write to:

\section{District Chief}

U.S Geological Survey Mountain View Office Park

810 Bear Tavern Road, Suite 206

West Trenton, NJ 08628
Copies of this report can be obtained from:

U.S Geological Survey Earth Science Information Center Open-File Reports Section Box 25286, MS 517 Denver Federal Center Denver, CO 80225 


\section{CONTENTS}

Page

Abstract

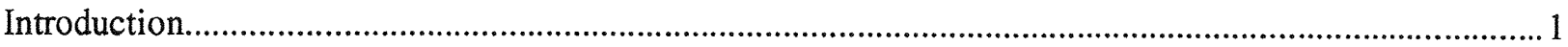

Methods for determining flood magnitude and frequency ............................................................... 1

New Jersey Department of Environmental Protection Special Report 38 method...................................... 3

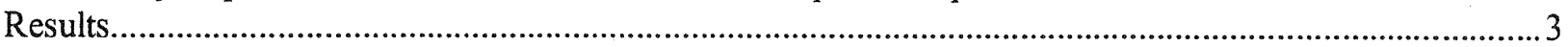

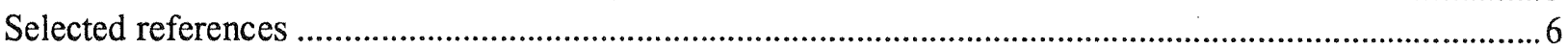

\section{ILLUSTRATIONS}

Figure 1. Map showing location of Franklin Pond tributary at the culvert at milepost 32.2 on New Jersey Route 23 and associated drainage basin, Franklin Borough, New Jersey.............2

\section{TABLES}

Table 1. Explanatory variables for the flood-magnitude and -frequency analysis of Franklin Pond tributary at the culvert on New Jersey Route 23, milepost 32.2, Franklin Borough, New Jersey

2. Estimates of flood magnitudes for selected flood frequencies for Franklin Pond tributary at the culvert on New Jersey Route 23, milepost 32.2, Franklin Borough, New Jersey 


\section{CONVERSION FACTORS}

$\underline{\text { Multiply }}$

foot (ft)

mile (mi)

square mile $\left(\mathrm{mi}^{2}\right)$

foot per mile ( $\mathrm{ft} / \mathrm{mi}$ )

cubic foot per second $\left(\mathrm{ft}^{3} / \mathrm{s}\right)$
By

To obtain

0.3048

1.609

2.590

0.189

0.0283 meter

kilometer

square kilometer

meter per kilometer

cubic meter per second 


\title{
FLOOD MAGNITUDE AND FREQUENCY OF FRANKLIN POND TRIBUTARY AT THE CULVERT ON NEW JERSEY ROUTE 23, FRANKLIN BOROUGH, SUSSEX COUNTY, NEW JERSEY
}

\author{
By Thomas Barringer
}

\begin{abstract}
Flood magnitude and frequency values are presented for the Franklin Pond tributary at the culvert at milepost 32.2 of New Jersey Route 23, Franklin Borough, New Jersey. The values were determined by using New Jersey Department of Environmental Protection Special Report 38 method. A description of the drainage-basin characteristics also is included in this report. The 100-year-flood estimate is 218 cubic feet per second.
\end{abstract}

\section{INTRODUCTION}

Information on the magnitude and frequency of floods is critical to the planning and design of highway culverts and bridges. Such information is not readily available for many stream crossings in New Jersey. To fulfill this information need, the U.S. Geological Survey (USGS), in cooperation with the New Jersey Department of Transportation, began an analysis of flood data from stream-crossing sites on New Jersey streams.

This report presents results of the analysis for Franklin Pond tributary at the culvert at milepost 32.2 of New Jersey Route 23, Franklin Borough, New Jersey. The culvert is located about one-half mile north of the electrical substation south of Franklin Borough, New Jersey (fig. 1). The drainage area upstream from the site is estimated to be $0.82 \mathrm{mi}^{2}$. A field reconnaissance was performed on May 18, 1995 , to verify the location of the drainage-basin divide and basin characteristics. Because the upper part of the drainage basin is steep, heavily wooded, and roadless, the calculated drainage area is approximate.

Part of the subject basin lies within Franklin Borough. The flood-insurance study for Franklin Borough, Sussex County, New Jersey, (Federal Emergency Management Agency, 1983) does not include a detailed study of this stream; therefore, flood discharges were not determined previously.

\section{METHODS FOR DETERMINING FLOOD MAGNITUDE AND FREQUENCY}

Various widely used methods for calculating flood magnitude and frequency were considered for use in determining the flood magnitudes that are likely to be exceeded at this site within a given number of years (recurrence interval). The rational method (Chow and others, 1988), New Jersey Department of Environmental Protection (NJDEP) Special Report 38 method (SR 38) (Stankowski, 1974), the U.S. Soil Conservation Service (SCS) Technical Release 55 (TR-55) method (U.S. Soil Conservation Service, 1986), the USGS transfer method (New Jersey Department of Environmental Protection, 1988), and the index-flood method (Thomas, 1964) were all considered for use in determining flood magnitude and frequency at the subject culvert. 

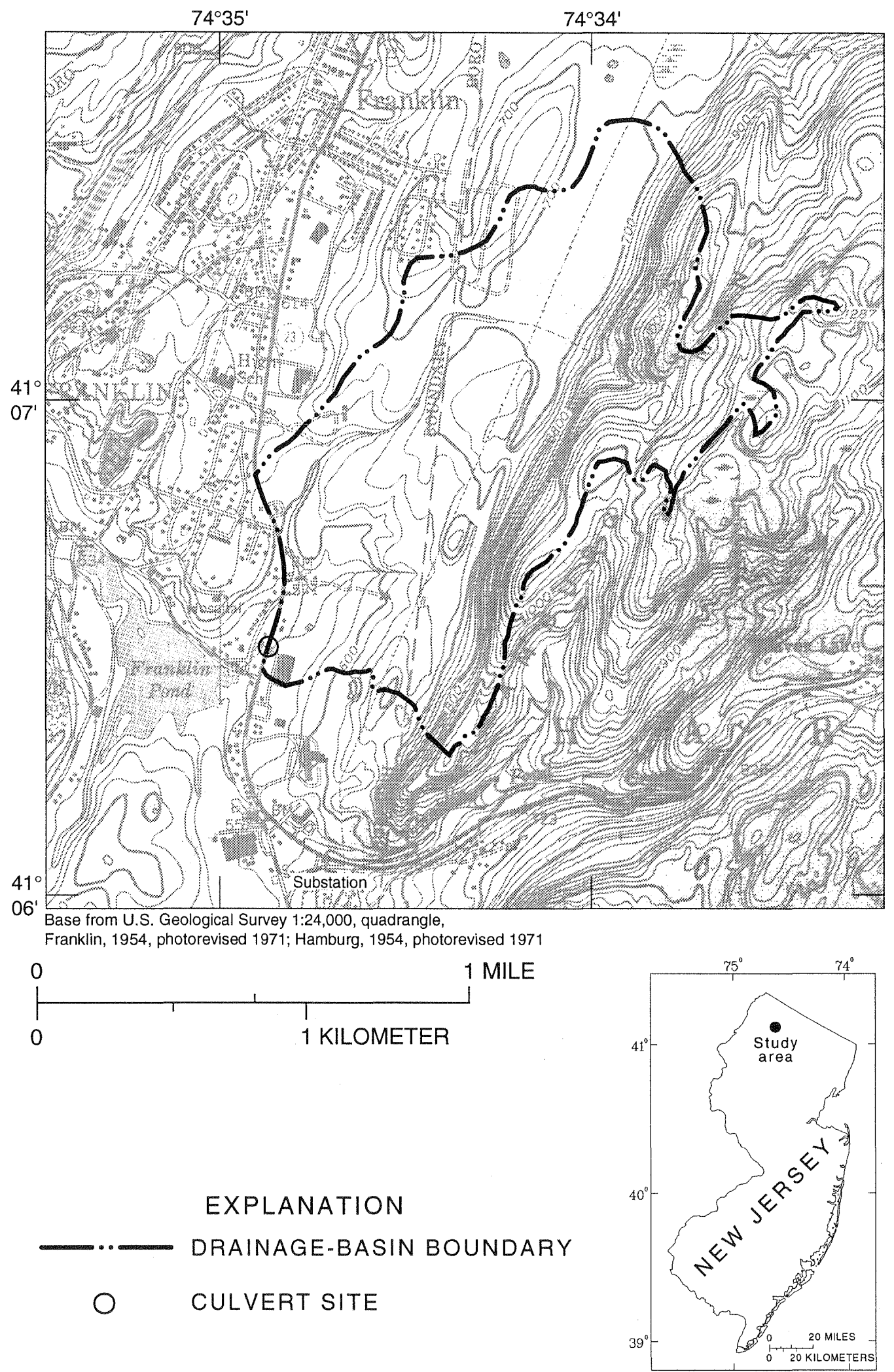

Figure 1. Location of Franklin Pond tributary at the culvert at milepost 32.2 on New Jersey Route 23 and associated drainage basin, Franklin Borough, New Jersey. 


\section{NEW JERSEY DEPARTMENT OF ENVIRONMENTAL PROTECTION SPECIAL REPORT 38 METHOD}

The Special Report 38 method (Stankowski, 1974) was developed for use with drainage basins of 1 to $1,000 \mathrm{mi}^{2}$. The subject basin has an area of $0.82 \mathrm{mi}^{2}$, but is sufficiently close to the $1 \mathrm{mi}^{2}$ lower limit for this method to be acceptable. In addition, the estimates calculated with this method were in fairly close agreement with those made by using the USGS transfer method.

Flood data from four streamflow gages located in basins with characteristics similar to the subject basin and located within a 41-mi radius of the culvert site were examined to determine whether the SR 38 method provides reasonable estimates of flood magnitude when compared with USGS transfer method estimates of peak discharge. Flood magnitude and frequency computed by using the SR 38 method were also compared with estimates made by using the rational method and the TR-55 method.

The estimates of the 100-year flood made for the New Jersey Route 23 site by using the rational method and the TR-55 method were 5.8 and 4.7 times, respectively, the estimates obtained by using the SR 38 method. The estimate of the 100-year flood at the subject site using the SR 38 method was 1.3 times the average discharge estimate made by using the USGS transfer method with flood data from four gage sites (Furnace Brook at Oxford, New Jersey, station 01445490; Pequest River at Huntsville, New Jersey, station 01445000; Mulhockaway Creek at Van Syckel, New Jersey, station 01396660; and Quaker Creek at Florida, New York, station 01369500). The SR 38 estimate was chosen because of its close general agreement with the USGS transfer method estimates. Also, estimates made by using the rational and TR-55 methods were not chosen because these methods produced overestimates of flood magnitude in some areas of New Jersey (R.D. Schopp, U.S. Geological Survey, oral commun., 1995).

\section{RESULTS}

Flood data from nearby streamflow or crest-stage gaging stations provide a good indication of the flood magnitude and frequency that can be expected at an ungaged site, particularly when the drainage area and other basin characteristics are similar. In this study, estimates obtained by using the New Jersey Department of Environmental Protection Special Report 38 method were compared with estimates made by using the USGS transfer method. In addition, the SR 38 estimate was compared with estimates made by using the rational method and the TR-55 method.

Variables used in computing the SR 38 method flood-magnitude and -frequency estimates are listed in table 1. The estimates made by using the SR 38 method are listed in table 2 . The estimate of the 100 -year flood discharge at the culvert site is $218 \mathrm{ft}^{3} / \mathrm{s}$. 
Table 1. Explanatory variables for the flood-magnitude and -frequency analysis of Franklin Pond tributary at the culvert on New Jersey Route 23, milepost 32.2, Franklin Borough, New Jersey

Drainage area: 0.82 square miles

Latitude: $41^{\circ} 06^{\prime} 31^{\prime \prime}$

Longitude: $74^{\circ} 34^{\prime} 53^{\prime \prime}$

Highway: New Jersey Route 23

Milepost: 32.2

U.S.Geological Survey 7-1/2-minute quadrangles: Hamburg and Franklin, N.J.

\begin{tabular}{llcl}
\hline \multicolumn{1}{c}{ Variable } & & Value & Unit \\
\hline Drainage area & $=$ & 0.82 & square miles \\
Main-channel slope & $=$ & 447 & feet per mile \\
Surface-storage index & 11.0 & percent \\
Total stream length & $=$ & 1.78 & mile \\
Population density (1990) & $=$ & 385 & persons per square mile \\
Impervious cover & $=$ & 7.16 & percent \\
Lake and swamp area & $=$ & 10.0 & percent \\
\hline
\end{tabular}


Table 2. Estimates of flood magnitudes for selected flood frequencies for Franklin Pond tributary at the culvert on New Jersey Route 23, milepost 32.2, Franklin Borough, New Jersey

$[Q$, flood-magnitude estimates in cubic feet per second along with number, indicating recurrence interval in years; NJDEP, New Jersey Department of Environmental Protection; SR, Special Report].

Drainage area: 0.82 square miles

Latitude: $41^{\circ} 06^{\prime} 31^{\prime \prime}$

Longitude: $74^{\circ} 34^{\prime} 53^{\prime \prime}$

Highway: New Jersey Route 23

Milepost: 32.2

U.S.Geological Survey 7-1/2-minute quadrangles: Hamburg and Franklin, N.J.

\begin{tabular}{lllllll}
\hline Estimating method & Q2 & Q5 & Q10 & Q25 & Q50 & Q100 \\
\hline NJDEP SR 38 & 42 & 69 & 98 & 140 & 173 & 218 \\
\hline
\end{tabular}




\section{SELECTED REFERENCES}

Chow, V.T., Maidment, D.R., and Mays, L.W., 1988, Applied hydrology: New York, McGraw-Hill, 572 p.

Federal Emergency Management Agency, 1983, Flood insurance study of Franklin Borough, New Jersey: Federal Emergency Management Agency, September 15, 1983, 14 p., 3 pls., 1 panel.

New Jersey Department of Environmental Protection, 1988, Technical manual for stream encroachment: New Jersey Department of Environmental Protection, Division of Water Resources, Bureau of Floodplain Management, 151 p. 6 app.

Stankowski, S.J., 1974, Magnitude and frequency of floods in New Jersey with effects of urbanization: New Jersey Department of Environmental Protection, Special Report 38, 46 p.

Thomas, D.M., 1964, Floods in New Jersey, magnitude and frequency: New Jersey Department of Conservation and Economic Development, Water Resources Circular 13, 145 p.

U.S. Soil Conservation Service, 1986, Urban hydrology for small watersheds: Engineering Division Technical Release 55, Washington, D.C., 162 p. 